
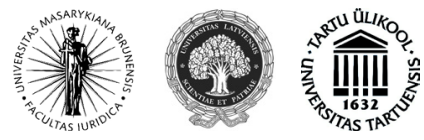

ISSN 1392-6195 (print) ISSN 2029-2058 (online) JURISPRUDENCIJA JURISPRUDENCE 2014, 21(3), p. 885-906.

\title{
FIZINIO SMURTO SPORTE BAUDŽIAMASIS TEISINIS IVERTINIMAS
}

\author{
Linas Žalnieriūnas, Aurelijus Gutauskas \\ Mykolo Romerio universiteto Teisès fakulteto \\ Baudžiamosios teisès ir proceso institutas \\ Ateities g. 20, LT-08303 Vilnius, Lietuva
}

Tel. (+370 5) 2714618

Elektroninis paštas: linaszalnieriunas@gmail.com; a.gutauskas@lat.lt

Pateikta 2014 m. liepos 16 d., parengta spausdinti 2014 m. rugsejo $18 \mathrm{~d}$.

doi:10.13165/JUR-14-21-3-12

\section{Ivadas}

Sportas - fizinės veiklos forma, reikalaujanti varžymosi maksimaliomis dvasinèmis ir fizinėmis pastangomis, visa tai darant laikantis pagarbos varžovui, garbingos kovos ir taikos principų. Tačiau pasitaiko atvejų, kai sportininkai naudoja fizinę jègą vadovaudamiesi ne sportiniais principais ir tikslais, o kitais motyvais, - tiesiog išreiškia pyktį ar kompensuoja nesugebejjimą veikti pagal žaidimo taisykles. Sveikatos sutrikdymas, padarytas pažeidžiant sportines taisykles, yra nepageidaujamas rezultatas, ypač jei tai daroma tikslingai. Pasaulyje netrūksta tokių pavyzdžių - Myke`o Tysono ir Evander Hollyfiealdo bokso dvikova, kurios metu Myke'as Tysonas nukando dali ausies savo oponentui ${ }^{1}$, arba pasaulio futbolo čempionato varžybos tarp Urugvajaus ir Italijos komandų, kuriose Luisas Suarezas ịkando varžovui i petị ${ }^{2}$, ledo ritulio var-

1 Mike Tyson vs Evander Holyfield II [interaktyvus]. [žiūrèta 2014-07-05]. <http://www. youtube.com/watch?v=fcXYEIhy-rc $>$.

2 Futbolo košmarai: Luisas Suarezas vél kandžiojasi? [interaktyvus]. [žiūrèta 2014-07-05]. $<$ http://www.zinios.lt/sportas/zinia/2014/06/24/futbolo-kosmarai-liusas-suarezas-velkandziojasi/>.

Jurisprudencija/Jurisprudence

(C) Mykolo Romerio universitetas, 2014

(C) Mykolas Romeris University, 2014
ISSN 1392-6195 (print), ISSN 2029-2058 (online) http://www.mruni.eu/lt/mokslo_darbai/jurisprudencija/ http://www.mruni.eu/en/mokslo_darbai/jurisprudencija/ 
žybos tarp Lietuvos ir Serbijos rinktinių, kurių metu itin agresyviai susimušè abiejų komandų žaidèjai, o vèliau Serbijos rinktinès sportininkų išpuolis prieš žiūrovus ${ }^{3}$, neseniai ịvykęs incidentas krepšinio aikštelèje tarp Vilniaus Lietuvos ryto ir Utenos Juventus komandų, kurių metu Vilniaus žaidejjas Dovydas Redikas kumščiu į veidą smogè priešininkų komandos žaidejjui ${ }^{4}$, ir daugelis kitų atvejų, kurie teisiškai nebuvo ivertinti.

Todèl kyla klausimas, ar tyčinis fizinis smurtas turi būti teisiškai ịvertintas, o žalą sukèlę sportininkai privalo atsakyti baudžiamąja tvarka už neteisètą fizinio smurto naudojimą? Jei ne, ar tuomet pripažizstame, kad sportas yra specifinè sritis, kurioje galima teisètai smurtauti siekiant ir ne sportinių tikslų? Pritariant rusų mokslininkams, baudžiamosios teisès mokslo esmé - nustatyti ribas, kada sporto varžybų metu padaryti sveikatos sutrikdymai laikomi nusikalstamomis veikomis ${ }^{5}$.

Baudžiamosios atsakomybės už fizinio smurto naudojimą sporte praktinès bei teorinès problemos moksliniu lygiu Lietuvoje nebuvo analizuotos. Todèl straipsnyje siekiama teisiškai ịvertinti fizinès jègos naudojimą ne sportiniais tikslais, o kaip priemonę susidoroti su emociją sukẻlusiu sportininku, varžybų teisẻju ar žiūrovu. Užsienio šalyse (JAV, Didžioji Britanija ir kt.) šiai problemai skiriama nemažai mokslininkų dèmesio, juolab kad ir Lietuvoje pasitaiko fizinio smurto atvejų sporte. Todèl analizuojama tema pasižymi moksliniu naujumu ir aktualumu.

Darbo tikslas - pateikti galimus objektyvius kriterijus, padėsiančius tinkamai teisiškai įvertinti fizinio smurto sporte atvejus bei identifikuoti nusikalstamų veikų inkriminavimo galimybes.

Tyrimo objektas - sportininko veiksmai varžybų metu, kuriais padaroma žala sveikatai bei su jais susijusi baudžiamosios teisès doktrina ir teismų praktika.

Tyrimo metodai - sisteminès ir dokumentų analizès, lyginamasis, formalusis teisinis, loginis bei gramatinis.

\section{Teisinè fizinio smurto sporte samprata}

\subsection{Teisinis fizinio smurto sporte reglamentavimas Lietuvoje ir užsienio šalyse}

Tarptautinis teisinis fizinio smurto reguliavimas sporte yra itin skurdus. Paminètina bene vienintelè Europos konvencija dèl žiūrovų brutalaus elgesio per sporto

3 Hockey Lietuva-Serbija mustynes/ Fighting in ice hockey [interaktyvus]. [žiūrèta 2014-07-05]. $<$ http://www.youtube.com/watch?v=lL_MLSTrfhg $>$.

4 Lietuvos Rytas-Juventus TEAM FIGHT (FULL) [interaktyvus]. [žiūrèta 2014-07-05]. <https:// www.youtube.com/watch?v=HIAldkhA7gY>.

5 Skvorcov, A. A. Prichinenija vreda zhizni $i$ zdorovju pri zaniatijam sportom. Problemy ugolovnoj-pravovoj kvalifikacii. [Damage for the health and life at doing sports. Problems of the criminal law qualification.]. Moskva, 2006, p. 66. 
varžybas ir ypač futbolo renginius ${ }^{6}$. Tuo tarpu fizinio smurto tarp žaidejjų reglamentavimo nèra, o remiamasi bendraisiais Europos žmogaus teisių konvencijos principais, skelbiančiais, jog žmogaus kūnas neliečiamas, niekas negali patirti fizinio smurto ${ }^{7}$. Vadinasi, valstybès, pasitelkdamos nacionalinę teisę, pačios reguliuoja fizinio smurto sporte traktavimą ir atsakomybę už jo panaudojimą.

Paminètina, kad daugelis šalių (JAV, Kanada, Vokietija, Rusija, Gruzija ir kt.) baudžiamuosiuose ịstatymuose nèra numačiusios nusikalstamos veikos sudèties išskirtinai už fizinio smurto panaudojimą sporte. Vis dèlto šių šalių baudžiamuosiuose istatymuose yra ịtvirtintos normos, numatančios sporto metu padarytus sveikatos sutrikdymus kaip baudžiamąją atsakomybę šalinančias aplinkybes, kitose tokie atsitikimai priskiriami prie nelaimingų atsitikimų arba kazusų.

Junginių Amerikos Valstijų pavyzdiniame kodekse ${ }^{8}$ yra nurodyta, kad sveikatos sutrikdymai, padaryti sportinių renginių metu, neužtraukia baudžiamosios atsakomybės, jeigu: a) sportinis renginys buvo teisètas, b) sveikatos sutrikdymas padarytas laikantis taisyklių, c) buvo duoti sporto renginyje dalyvaujančių asmenų sutikimai.

Paminètina, jog Kanados baudžiamojo kodekso 83 straipsnyje numatyta baudžiamoji atsakomybẻ už kontaktinio nelegalaus sporto organizavimą. Kontaktinis nelegalus sportas suprantamas kaip nelegalios dvikovos tarp dviejų asmenų. Baudžiamojon atsakomybèn traukiami tik organizatoriai. Kovotojai atsakomybès išvengia, kadangi duoda sutikimą tokioms dvikovoms ${ }^{9}$.

Vokietijos baudžiamojo kodekso 228 straipsnis nurodo, kad gavus asmens sutikimą leidžiami sveikatos sutrikdymai, išskyrus atvejus, kai tokie sutrikdymai prieštarauja visuotinai priimtoms moralès normoms ${ }^{10}$.

Afganistano baudžiamajame kodekse numatyta, kad baudžiamąją atsakomybę šalinančia aplinkybe laikytinas sveikatos sutrikdymas, padarytas sportinio renginio metu, jei tai įvyko laikantis nustatytų taisyklių ${ }^{11}$. Todèl jei sveikatos sutrikdymas sportinio renginio metu buvo padarytas pažeidžiant sporto šakos taisykles, taikytina baudžiamoji atsakomybė. Labai panaši norma numatyta ir San Marino baudžiama-

6 Europos Konvencija dèl brutalaus žiūrovų elgesio per sporto varžybas ir ypač per futbolo rungtynes [interaktyvus]. [žiūrèta 2014-07-06]. <http://www3.lrs.lt/pls/inter3/dokpaieska. showdoc_l?p_id=104182\&p_tr2=2>.

7 Europos žmogaus teisių ir pagrindinių laisvių apsaugos konvencija [interaktyvus]. [žiūrèta 201407-06]. <http://www3.lrs.lt/pls/inter3/oldsearch.preps2?Condition1=19841\&Condition2=>.

8 Criminal Code of USA [interaktyvus]. [žiūrèta 2014-07-06]. <http://www.law.cornell.edu/ uscode/text/18/part-I>.

9 Criminal Code of Canada (English and French) [interaktyvus]. [žiūrèta 2014-07-06]. <http:// www.legislationline.org/documents/section/criminal-codes>.

10 Criminal Code of the Federal Republic of Germany (English and French) [interaktyvus]. [žiūrèta 2014-07-06]. <http://www.legislationline.org/documents/section/criminal-codes>.

11 Criminal Code of Afganistan [interaktyvus]. [žiūrèta 2014-07-06]. <https://www.unodc.org/ tldb/showDocument.do?documentUid=2100>. 
jame kodekse, kuriame pasakyta, kad sveikatos sutrikdymas sportinio renginio metu yra pateisinama aplinkybė, išskyrus atvejus, kai tai padaryta pažeidžiant numatytas taisykles $^{12}$.

Gruzijos baudžiamojo kodekso 32 straipsnyje ${ }^{13}$ nurodyta, kad asmuo, padaręs kodekse numatytą nusikalstamą veiką, gali būti netraukiamas baudžiamojon atsakomybèn, jei sutrikdymas padarytas teisètais, nors ir kodekse nenumatytais, veiksmais. Todèl šiame kodekse būtina sąlyga - teisètumas. Tad jeigu sportinis renginys buvo teisètas, jo metu teisètais veiksmais sveikatą sutrikdęs sportininkas nebus traukiamas baudžiamojon atsakomybèn.

Tuo tarpu Lietuvos baudžiamojo kodekso (toliau - BK) V skyriuje tarp pateiktų baudžiamąją atsakomybę šalinančių aplinkybių apie sporto renginius ir jų metu sukeltus padarinius neužsimenama. Tačiau Lietuvai pavyzdys gali būti Ispanija, kur asmens, panaudojusio fizinị smurtą sporte, veiksmai nelaikomi nusikalstamais, jeigu asmuo elgèsi teisètai ir tai buvo padaryta vykdant profesines pareigas ${ }^{14}$.

Aplinkybé, galinti tikti tokiai situacijai, yra BK 34 straipsnyje „Pateisinama profesinè ar ūkinè rizika" ${ }^{15}$. İstatymų leidejjas kurdamas šią normą nenumatè galimybés jos taikyti sporto renginiams ir jų metu padarytiems sveikatos sutrikdymams. Tačiau tai galètų būti logiška išeitis, siekiant teisiškai ịvertinti sveikatos sutrikdymą padariusio asmens veiksmus. Kitas kelias yra sukurti naują baudžiamąją atsakomybę šalinančią aplinkybę, kuri reglamentuotų atvejus, kai sutrikdoma sveikata ar net atimama gyvybė būtent sporto varžybų metu. Tačiau tokių normų kūrimas būtų netikslingas, kadangi objektyvioje tikroveje gali susidaryti daugybe situacijų, kurios tiesiogiai nebus aptartos baudžiamajame įstatyme, tačiau kurias galima aiškinti jau esamomis teisès normomis. Remiantis Aharono Barako žodžiais: „_...>turi rūpèti ne naujos teisès kūrimas, o jau egzistuojanti teisé, kuriai turi būti suteikiama nauja prasmè. Tokiu būdu galiojantys įstatymai suderinami su besikeičiančia socialine realybe. "16 Sutinkant su tuo, ị jau turimą BK 34 straipsnio normą derètų žvelgti plačiau, taip prisitaikant prie tikrovès kuriamų naujų situacijų, užuot kiekvienai naujai situacijai kuriant naują istatymo normą.

Normos kontekste profesinė rizika galima bet kurioje sąmoningoje žmogaus veiklos sferoje ir yra socialiai vertinga visuomenei, kadangi jos metu yra siekiama legislation. The criminal code of the republic of San Marino]. Sankt-Peterburg, 2002.

13 Criminal Code of Georgia (English and French) [interaktyvus]. [žiūrèta 2014-07-06]. <http:// www.legislationline.org/documents/section/criminal-codes>.

14 Criminal Code of Spain (English and French) [interaktyvus]. [žiūretta 2014-07-06]. <http:// www.legislationline.org/documents/section/criminal-codes $>$.

15 Lietuvos Respublikos baudžiamasis kodeksas. Valstybės žinios. 2000, Nr. 1968. 34 str.

16 Barak, A. The judge in the democracy. Princeton2006, p. 5 
visuomenei naudingų tikslų ${ }^{17}$. Šiuo atveju sportas neabejotinai priskirtinas prie visuomenei naudingos veiklos, o sportininkai, užsiimantys konkrečia sporto šaka, laikytini asmenimis, užsiimančiais profesine veikla bei siekiančiais visuomenei naudingų tikslų.

Baudžiamosios teisès teorijoje yra keliami profesinès rizikos teisètumo reikalavimai: ${ }^{18}$ 1) padaryti veiksmai turi atitikti šiuolaikinius mokslo pasiekimus, reiškia, kad asmuo atsižvelgè ị savo profesinị pasirengimą, vadovavosi atitinkamomis rekomedacijomis. Be to, būtinas veiksmų pagrindimas, jų modeliavimas ir bent jau apytikris rezultatas; 2) norimo tikslo negalima pasiekti be rizikos. Šiuo atveju būtinas norimo tikslo ir rizikos (galimos žalos) palyginimas, nes reikšmingesnis tikslas pateisina didesnę riziką. Būtina siekti mažiausios galimos žalos. Atkreiptinas dèmesys ị tai, kad sportininkai išreiškia sutikimą dèl galimų sveikatos sutrikdymų (sūsidūrimai žaidybinèse situacijose, kuriu metu galimi sveikatos sutrikdymai). Todèl sportininko sutikimas patenka ị baudžiamąją atsakomybę šalinančios aplinkybès turini, turint omenyje, jog norimo tikslo negalima pasiekti be galimos rizikos sveikatai; 3) buvo imtasi visų galimų saugumo priemonių, užkertančių kelią žalai atsirasti. Šis reikalavimas atskleidžia profesinės rizikos esmę, kad asmuo siekdamas išvengti žalos kilimo pasitelke savo profesines žinias, patirtị ir kt. priemones.

Tuo tarpu veiksmai, kuriais peržengiama pateisinama rizika, yra pavojingi ir gali sudaryti nusikaltimo sudèț. Pateisinamos rizikos ribų peržengimas galimas tik esant nusikalstamam pasitikèjimui, kai asmuo suvokia galimų pavojingų pasekmių atsiradimą, tačiau lengvabūdiškai tikisi jų išvengti. Pateisinamos rizikos ribų peržengimas negalimas esant tyčiai, kadangi tai pašalintų pateisinamumo momentą, ir nusikalstamam nerūpestingumui, nes rizika turi būti iš anksto apgalvota.

Pažymètina ir tai, kad sveikatos sutrikdymo ar gyvybès atėmimo sporte situacijos gali būti vertinamos ir kaip kazusas, kadangi remiantis baudžiamosios teisès teorija kazusas suprantamas kaip veikimas be kaltès, kai konkrečius veiksmus atlikdamas asmuo nenumaté, kad dèl jo veiksmų gali kilti neigiami padariniai ir pagal savo asmenines savybes ir veikos aplinkybes negalëjo ir neturejjo numatyti ( $p v z$., kamuolys, atšokęs nuo krepšinio lentos, pataiko žaidèjui i galvos sriți, dèl ko šis miršta) arba atlikdamas veiksmus ėmėsi visų galimų atsargumo priemonių, siekdamas išvengti neigiamų padarinių, tačiau padariniai vis vien kilo $^{19}$. Žinoma, skirtingose sporto šakose kyla sunkumų ižvelgiant kazusą - sunku teigti, kad asmuo èmési visų atsargumo priemonių, norèdamas išvengti tokių padarinių - bokso varžybose tyčia smūgiuodamas varžovui ị galvos sriți, taip pasiųsdamas jị i̇ nokautą, atima varžovui gyvybę. Žinoma,

17 Baranskaitė, A. Lietuvos Respublikos baudžiamojo kodekso komentaras. Bendroji dalis [interaktyvus]. [žiūrèta 2014-07-13]. <http://web.b.ebscohost.com/ehost/viewarticle?data=d GJyMPPp44rp2\%2fdV0\%2bnjisfk5Ie45PFJt6uxSbSk63nn5Kx95uXxjL6orUm1pbBIr6qeS7ipt 1Kxq55Zy5zyit\%2fk8Xnh6ueH7N\%2fiVaunr0mzp7VQtKm3PurX7H\%2b72\%2bw\%2b4ti7ebf epIzf3btZzJzfhruosUqyqrdQr5zkh\%2fDj34y75uJ\%2bxOvqhNLb9owA\&hid=119>, p. 213.

$18 \quad$ Ibid.

19 Piesliakas, V. Lietuvos baudžiamoji teisè. Pirmoji knyga. Vilnius: Justitia, 2009, p. 432. 
galima teigti, jog bokso pirštinès, šalia bokso ringo budintis medicinos personalas, kovą kontroliuojantis teisejjas yra būtent tos sąlygos, kurių imamasi siekiant išvengti neigiamų padarinių, tačiau sportininkas siekia kuo sunkiau sutrikdyti sveikatą savo oponentui. Todèl manytina, kad tokie tyčiniai veiksmai šalina galimybę remtis kazusu.

Pritariant A. Skvorcovo nuomonei, galima teigti, kad daugelio šalių teisinė sistema nenumato baudžiamosios atsakomybès už sveikatos sutrikdymą ar gyvybès atèmimą sporto varžybų metu, kadangi tokios situacijos vertinamos kaip baudžiamąją atsakomybę šalinanti aplinkybè su sąlyga, kad sportinis renginys buvo teisètas ir sportininkas, sukèlęs padarinius, nepažeidè žaidimo taisyklių ${ }^{20}$.

\subsection{Fizinès jejgos naudojimas sporte}

Fizinis varžymasis žmonijos istorijoje žinomas nuo pačiu pirmųjų civilizacijų, kai daugelis sporto formų buvo itin žiaurios dèl naudojamos šiurkščios, nevaržomos fizinès jègos ${ }^{21}$ Todèl nuo seno fizinis varžymasis - toleruojamos fizinès jègos naudojimo sfera, kur kasdieniame gyvenime draudžiama fizinè jẻga galèjo būti naudojama varžymosi tikslais.

Sportas šiandien - pagal tam tikras taisykles organizuojama specifinè fizinių ir intelektinių užsiemimų rūšis, derinant fizinius ir intelektinius gebejjimus, skirta varžymuisi ${ }^{22}$. Todèl pagrindinè sporto, kaip veiklos, išraiška - kūno judesiai, fizinès jègos naudojimas. Sportas tarytum unikali ir išskirtinè gyvenimo sritis, kur už atitinkanti taisykles fizinès jẻgos naudojimą asmenims nekyla teisinè atsakomybè, ir, priešingai - sportininkai, pasižymintys geresnèmis fizinèmis savybėmis, efektyvesniu jègos naudojimu, yra sveikinami, gerbiami ir net šlovinami.

Vis dèlto îvairios sporto šakos turi savitas taisykles, sudarančias konkrečios sporto šakos varžymosi procesą, jo esmę. Šios taisyklès detaliai reglamentuoja, kokiu būdu gali būti naudojama fizinè jèga (kontaktas) varžybų metu.

20 Skvorcov, A. A., supra note 5, p. 72.

21 Guilbert, S. Violence in sports and among sportsmen: a single or two-track, Issue? Aggressive Behavior. 2006, Vol. 32, Issue 3: 2 [interaktyvus]. [žiūretta 2014-07-07]. <http://web.b.ebscohost. com/ehost/viewarticle?data=dGJyMPPp44rp2\%2fdV0\%2bnjisfk5Ie45PFJt6uxSbSk63nn5Kx9 5uXxjL6orUm1pbBIr6qeS7ipt1Kxq55Zy5zyit\%2fk8Xnh6ueH7N\%2fiVaunr0mzp7VQtKm3P urX7H\%2b72\%2bw\%2b4ti7ebfepIzf3btZzJzfhruotkyzrLdKtpzkh\%2fDj34y75uJ\%2bxOvqhNL b9owA\&hid=119>.

22 Kerr, J. H. Analysis of recent incidents of on-field violence in sport: legal decisions and additional considerations from psychology. Aggressive Behavior. 2009, Vol. 35, Issue 1: 41 [interaktyvus]. [žiūrèta 2014-07-07]. <http://web.b.ebscohost.com/ehost/viewarticle?data=d GJyMPPp44rp2\%2fdV0\%2bnjisfk5Ie45PFJt6uxSbSk63nn5Kx95uXxjL6orUm1pbBIr6qeS7ipt 1Kxq55Zy5zyit\%2fk8Xnh6ueH7N\%2fiVaunr0mzp7VQtKm3PurX7H\%2b72\%2bw\%2b4ti7ebf epIzf3btZzJzfhrups0\%2bvrK9Qt5zkh\%2fDj34y75uJ\%2bxOvqhNLb9owA\&hid=119> 
Toliau straipsnyje analizuojamas kontaktinis sportas (angl. contact sport; rus. контактный спорт ${ }^{23}$ ), pasireiškiantis sporto šakos arba rungties, kuriose sportinès kovos dalyvių tarpusavio sąlytis (susidūrimas) yra leidžiamastaisyklių, t. y. sudedamoji sporto šakos dalis. Tai boksas, futbolas, regbis, ledo ritulys, krepšinis, kovos menai ir kt. Kanados sociologijos mokslo atstovas Mike'as Smith'as siūlo tokius fizinès jègos naudojimo kontaktiniame sporte tipus ${ }^{24}$ :

a) Stiprus fizinis kontaktas, kai žaidimo taisyklemis leidžiama fizinè jèga nukreipta į varžovo kūną, siekiant sutrikdyti jam sveikatą, turint tikslą eliminuoti varžovą iš varžybų priverčiant pasiduoti naudojant fizinị skausmą sukeliančius veiksmus arba kūno judesiais sutrikdant sveikatą, dèl ko oponentas fiziškai nebegali tęsti kovos (boksas, kovos be taisyklių, imtynės ir kt.).

b) Ribinis smurtas, kai fizinè jèga tiesiogiai nenukreipta ị varžovo kūną, jos naudojimo paskirtis šalutinès su varžovu nesusijusios užduoties ịvykdymas (įmesti kamuoli i krepšį, įmušti j̣vartị ir pan.) krepšinis, futbolas, regbis);

c) Kvazikriminalinis smurtas, kai taisyklèmis draudžiama, žaidime toleruojama, nerašyta norma tapusi, ribota fizinè jèga, tiesiogiai nukreipta i varžovo kūną, siekiant sutrikdyti jam sveikatą ir nesiekiant žaidimo tikslų (ledo ritulys);

d) Kriminalinis smurtas, kai šiurkščiai pažeidžiant taisykles fizinè jèga tiesiogiai nukreipta ị varžovo kūną, siekiant sutrikdyti sveikatą, neretai sukeliant sunkius padarinius.

Trys pirmieji fizinès jègos naudojimo tipai patenka ị „teisètą“, pagal sutartas taisykles naudojamą fizinę jègą. Kriminalinis smurtas išeina už priimtinos fizinès jègos pasireiškimo būdų, kai vienas iš sportininkų imasi itin agresyvios, neproporcingos ir šiurkščios jẻgos naudojimo, kuri nèra priimtina kitiems sportininkams, kadangi šiurkščiai pažeidžia žaidimo taisykles bei sukelia sveikatos sutrikdymus. Todèl atsiranda pagrindas taikyti teisès normas, numatančias atsakomybę už sveikatos sutrikdymus.

Tokia atsakomybès rūšimi galètų būti baudžiamoji atsakomybė. Baudžiamojoje teisèje fizinio smurto samprata apima veiksmus, kuriais pažeidžiama kito žmogaus kūno neliečiamybè, daroma žala sveikatai arba atimama gyvybè, taip pat ir veiksmus, kuriais siekiama tokią žalą padaryti ${ }^{25}$. Todèl pateiktas teisinis fizinio smurto apibrèžimas taikomas išskirtinai tais atvejais, kai fizinè jẻga naudojama šiurkščiai pažeidžiant sporto taisykles. Šiurkštų fizinès jègos naudojimą derètų suprasti kaip sportininko

23 žr. Sporto terminų žodyną. Sudarytijas S. Stonkus. Kaunas: Lietuvos kūno kultūros akademija, 2002, p. 553.

$24 R v$ Cey (1989), 48 CCC (3d) 480 (Sask CA) [interaktyvus]. [žiūrèta 2014-07-07]. <http:// casebrief.me/casebriefs/r-v-cey/>.

25 Grinevičiūtè, K. Žiauraus elgesio su vaiku samprata baudžiamojoje teisèje. Jurisprudencija. 2008, 11(113): 109. 
tyčinius kūno judesius, kuriais šiurkščiai pažeidžiant sportines taisykles siekiama sutrikdyti varžovo sveikatą, kai tai nèra varžybų tikslas.

\subsection{Sporto varžybų taisyklès}

Vystantis sporto kultūrai, žiaurios ir pavojingos fizinès jègos naudojimas buvo apribotas taisyklèmis, maksimaliai saugančiomis sportininkus nuo sužalojimų ${ }^{26}$. Šios taisyklès yra rašytinès, tvirtinamos konkrečios sporto šakos federacijos komitetų, neretai tarptautiniu lygiu (pvz., futbolo taisykles nustato Tarptautinè futbolo asociacija). Šių taisyklių laikosi visos šalys, kurios patenka ị konkrečios asociacijos sudètį. Šias tarptautines taisykles patvirtina šalių federacijos nacionaliniu lygiu. Sportininkai varžosi pagal šias taisykles, siekdami jų nepažeisti. Žaidimo taisyklès reglamentuoja visas galimas žaidimo situacijas, todèl numato ir tikètinus taisyklių pažeidimus - susidūrimus, už kuriuos pagal žaidimo taisykles skiriamos pražangos. Tokie prognozuojami susidūrimai yra ịtraukiami į žaidimo taisykles, kadangi priklausomai nuo konkrečios sporto šakos yra neišvengiami ir natūralūs, todèl tampa jų dalimi (pvz., pražanga krepšinyje), o patys žaidejjai duoda sutikimą konkretaus pobūdžio susidūrimams.

Kita vertus, neretai pasitaiko susidūrimų, kurie nẻra numatyti žaidimo taisyklèse ir už kuriuos skiriama griežčiausia sportinè nuobauda - diskvalifikacija. Tai dažnai šiurkštūs, su sporto tikslais nesuderinami susidūrimai. Toliau bus analizuojamas susidūrimų pobūdis ir jų santykis su baudžiamąja teise.

\subsubsection{Nerašytos taisyklès}

Kai kurių mokslininkų nuomone, taisyklių pažeidimai, galintys sukelti sveikatos sutrikdymus, gali būti teisèti, kadangi juos numato nerašytos žaidimo taisyklès (kvazikriminalinis smurtas). Šios nerašytos taisyklès yra neatsiejama žaidimo dalis, veikiau - žaidimo paprotys, tradicija. Kaip pavyzdi galima paminèti ledo ritulį, kuriame bene ryškiausiai iš visų sporto šakų naudojamas fizinis smurtas, kuris yra draudžiamas pagal žaidimo taisykles. Ledo ritulio varžybose dažnai ịvyksta muštynès, kurių metu varžovai kumščiais smūgiuoja vieni kitiems ị veidą (beveik ị vienintelę apsaugomis nepridengtą kūno vietą). Žaidimo taisyklès draudžia tokias muštynes, tačiau nerašytos žaidimo taisyklès tai toleruoja ${ }^{27}$.

26 Livings, B. 'Legitimate Sport' or Criminal Assault? What Are the Roles of the Rules and the Rulemakers in Determining Criminal Liability for Violence on the Sports Field? Journal of Criminal Law. 2006, Vol. 70, Issue 6: 499 [interaktyvus]. [žiūrèta 2014-07-05]. <http:// web.b.ebscohost.com/ehost/viewarticle?data=dGJyMPPp44rp2\%2fdV0\%2bnjisfk5Ie45PFJt6u xSbSk63nn5Kx95uXxjL6orUm1pbBIr6qeS7ipt1Kxq55Zy5zyit\%2fk8Xnh6ueH7N\%2fiVaunr0 mzp7VQtKm3PurX7H\%2b72\%2bw\%2b4ti7ebfepIzf3btZzJzfhruosUqyqrdQr5zkh\%2fDj34y7 $5 \mathrm{uJ} \% 2 \mathrm{bxOvqhNLb} 9$ owA\&hid=119>.

27 Standen, J. The manly sports: the problematic use of criminal law to regulate sports violance. Journal of Criminal Law \& Criminology. 2009, Vol. 99, Issue 3: 640 [interaktyvus]. [žiūrèta 2014-07-07]. <http://web.b.ebscohost.com/ehost/viewarticle?data=dGJyMPPp44rp2\%2fdV0 
Paminètina ir tai, kad būtent šioje sporto šakoje tam tikras žaidybines pozicijas užimančių sportininkų tiesioginè užduotis - traumuoti pagrindinius priešininkų komandos žaidejjus. Dar svarbiau, kad tokius nurodymus šiems žaidejjams duoda komandos treneriai. Iš kitos pusès, priešininkų komanda turi „apsauginị“, kurio tikslas saugoti pagrindinius žaidejus nuo fizinių išpuolių prieš juos bei traumuoti puolančius žaidejjus. Todèl dažnai šie žaidèjai susikimba, vienas prieš kitą naudodami agresyvų ir atvirą fizinị smurtą.

Tačiau nerašytos taisyklès turi tam tikrus ribojimus, kuriuos pripažįsta besivaržantys sportininkai. Ledo ritulio atveju nerašytos taisyklès pateisina tik tokias muštynes, kai fizinis smurtas naudojamas tarp dviejų oponentų, t. y. „vienas prieš vieną“. Mušantis dviem žaidejjams, kiti žaidejjai neturi kištis ir privalo leisti jiems „,išsiaiškinti“ žaidybinius santykius jèga, to nedaro ir teisejjai. Muštynių metu negalima smūgiuoti lazdomis, spirti pačiūžos geležte ${ }^{28}$. Todèl susidaro vaizdas, kad smurtas, pasireiškiantis atviromis muštynemis žaidimo aikštelëje, yra tam tikros nerašytos žaidimo taisyklès ar net šios sporto šakos tradicijos, formuojančios tikrąji ledo ritulio veidą. Tokias nerašytas taisykles pripažįsta ir su jomis sutinka besivaržantys sportininkai, tad panašu, kad baudžiamoji atsakomybè neturètų kilti.

Kita vertus, esama bylų, kuriose taisyklių pažeidimai, pasireiškiantys smurto demonstravimu, nors ir yra sistemiški, nèra toleruojami. Taip gali būti ir dèl to, kad pradejus toleruoti grubaus fizinio smurto naudojimą žaidimo metu, šis tampa žaidimo norma. O fizinis smurtas sporto žaidimo aikšteleje tampa pavyzdžiu ir smurto, naudojamo visuomeneje, šaltiniu. Naujosios Zelandjos teismas konstatavo, kad: „<...> faktas, jog žaidimo taisyklių pažeidimai nuolat ịvyksta, nereiškia, kad žaidejjams tokie pažeidimai yra priimtini. “29

Vis dèlto manytina, kad žaidimo taisyklių pažeidimus, pasireiškiančius fizinio smurto demonstravimu, teismas turi vertinti kiekvienoje konkrečioje situacijoje, spręsdamas, ar tokie pažeidimai turi būti vertinami baudžiamosios teisès prasme, ar ne, kadangi atsakymas nèra vienareikšmis ir gan sudètingas. Visų pirma taip yra dèl tikrojo sporto šakos turinio, kai nerašytos taisyklès yra itin svarbios ir neatsiejamos nuo rašytinių taisyklių. Antra - žaidèjai sutinka su galimais susidūrimais, tad tokie susidūrimai patenka ị žaidèjo sutikimo turinị. Todèl tokie susidūrimai priskiriami kvazikriminalinio smurto tipui, kadangi fizinis smurtas naudojamas ne žaidimo tikslais, turint tiesioginę tyčią sutrikdyti varžovo sveikatą, tačiau tokie veiksmai yra tapę nerašyta ir toleruojama žaidimo norma, su kurios egzistavimu sutinka besivaržantys

\%2bnjisfk5Ie45PFJt6uxSbSk63nn5Kx95uXxjL6orUm1pbBIr6qeS7ipt1Kxq55Zy5zyit\%2fk8Xn h6ueH7N\%2fiVaunr0mzp7VQtKm3PurX7H\%2b72\%2bw\%2b4ti7ebfepIzf3btZzJzfhruqsk\%2 buqbNRr5zkh\%2fDj34y75uJ\%2bxOvqhNLb9owA\&hid=119>.

28 Standen, J., supra note 27.

$29 R$ v. Ciccarelli [2011] All ER (D) 23 (Nov) [interaktyvus]. [žiūrèta 2014-07-07]. <http://www. criminallawandjustice.co.uk/clj-reporter/R-v-Ciccarelli-2011-All-ER-D-23-Nov>. 
sportininkai. Simonas Guardineris teigia, kad nerašytos taisyklès yra gan lanksčios, kadangi sportininkai, sutikdami su fizinio smurto naudojimu, sutinka ir su kylančiais padariniais bei atsakomybe už juos. Tai reiškia, kad kilus neigiamiems padariniams atsakomybe taip pat pripažistama ${ }^{30}$.

\subsubsection{Susidūrimai žaidybinèse ir nežaidybinèse situacijose}

„Vienokio ar kitokio intensyvumo fizinè jëga privalo būti naudojama žaidimo tikslais. Susidūrimai žaidybinèse situacijose neužtraukia baudžiamosios atsakomybès. Jeigu fizine jèga naudojama ne žaidimo tikslais, tokiu veiksmu negalima pateisinti žaidybiniu susidūrimu. Tokios fizinès jëgos panaudojimas privalo büti įvertintas istatymo." ${ }^{\text {i1 }}$

Todèl stengiantis atskirti draudžiamus susidūrimus, galinčius užtraukti baudžiamąją atsakomybę, būtina aptarti, kas yra žaidybinès ir nežaidybinès situacijos.

Susidūrimu žaidybinëje situacijoje derètų laikyti žaidèjų fizinị kontaktą, ịvykusị:

a) nepažeidžiant žaidimo taisyklių (neatsargūs susidūrimai) arba b) pažeidžiant taisykles, kai fizinè jèga nukreipta ị žaidimo ịrankị (pvz., kamuolį), arba c) pažeidžiant taisykles, kai fizinè jèga nukreipta ị žaidèją, tačiau nesistengiant jo sužaloti, o tik sulaikyti ar neleisti atlikti žaidybinių veiksmų (pvz., griebimas už marškinèlių, neleidžiant veržtis vartų link), d) tokie susidūrimai yra aptarti žaidimo taisyklèse, e) žaidèjai sutinka su susidūrimo galimybe ir jo apimtimi, f) tai daroma siekiant žaidimo tikslų,

Tuo tarpu susidūrimu nežaidybinèse situacijose derètų laikyti fizinị kontaktą, kuriuo:

a) pažeidžiamos žaidimo taisyklès, b) fizinè jèga nukreipta ne į žaidimo įrankị, o ị žaidèją, c) siekiama sužaloti žaidèją, d) nesiekiama žaidimo tikslų, e) susidūrimai neaptarti žaidimo taisyklèse, f) fizinis kontaktas išeina už sutikimo ribų ir apimties.

Atskiriant šias situacijas, galima pateikti tokius pavyzdžius: kaip žaidybinę situaciją derètų suprasti, kai futbolininkas koja smūgiuoja ị kamuolị, tačiau pataiko ị koją, taip padarydamas sveikatos sutrikdymą (dèl kurio žaidẻjas nebegali tęsti žaidimo). Tuo tarpu nežaidybinè situacija, kai futbolininkas tyčia spiria koja ị varžovą, neturintị kamuolio, arba varžovui, turinčiam kamuolį, bet ne ị kamuolị, taip sutrikdydamas jam sveikatą.

Būtent nežaidybinès situacijos, kai tyčia siekiama sutrikdyti sveikatą, gali būti vertinamos pasitelkiant teisinę atsakomybę, kadangi kaltininkas tyčia siekia sutrikdyti varžovo sveikatą ir siekia ne sportinių tikslų.

Atsižvelgiant ị užsienio šalių teismų praktiką, paminètinos bylos, kuriose teismai skirtingai vertina žaidybines ir nežaidybines situacijas atsižvelgdami taip pat ir ị

Ibid. 
judesiu instinktyvumą. Paminètina baudžiamoji byla, kurioje teismas pasisakè, kad: "fizine jèga, naudojama nors ir nežaidybinèse situacijose, gali būti pateisinama, kadangi fizinè jèga gali būti instinktyviu judesiu rezultatas. ${ }^{\text {"32 }}$

Instinktyvūs judesiai, dar kitaip - sąmonès nekontroliuojami, arba refleksiniai, judesiai, vertinant baudžiamosios doktrinos prasme, neturètų užtraukti baudžiamosios atsakomybès tokiu būdu veikusiam asmeniui, kadangi jo veiksmuose nèra vieno iš subjektyviojo požymio - kaltès. Asmuo nesuvokia, jog veikia pavojingai kito asmens atžvilgiu, nenumato, kad gali sutrikdyti sveikatą ar atimti gyvybę, ir to nenori. Toks veiksmų ịvertinimas kyla iš asmens negebejjimo kontroliuoti tokio pobūdžio nevalingų judesių, kadangi jie suponuoti refleksų ir atliekami nesąmoningai (pvz., mirksejimas, stumiamieji kūno judesiai reaguojant ị fizinị skausmą ir pan.).

\section{Sportininko sutikimo turinys ir apimtis: ar sportininko} sutikimas dalyvauti varžybose šalina baudžiamąją atsakomybę už sveikatos sutrikdymą ar gyvybės atėmimą?

\subsection{Sutikimo forma}

Atsižvelgiant ị jau aptartus užsienio šalių baudžiamuosius ịstatymus, sutikimas yra itin svarbus kvalifikuojant sveikatos sutrikdymą ar gyvybės atemimą sporto varžybų metu. Sutikimas suprantamas kaip sportininko suvokimas, jog yra tikètini taisyklių pažeidimai, kurių metu yra galimybè susižeisti ar būti sužeistam, ir tokio suvokimo valios išraiška, pasireiškianti rašytiniu (sutartys / kontraktai), formaliu sutikimu dalyvauti varžybose. Sutikimas turi apimti tik neatsargų sveikatos sutrikdymą ar gyvybès atemimą.

Analizuojant detaliau, sportininkas suvokia, kad susidūrimai žaidimo metu yra neišvengiami, o kai kuriose sporto šakose yra pagrindine varžymosi forma (kovos menai). Sutikdamas dalyvauti varžybose sportininkas sutinka su susidūrimo su varžovu galimybe, o ịvykus susidūrimui tai traktuojama kaip natūrali, kartais net naudinga (futbolo pražanga baudos aikštelèje), žaidimo dalis.

Kaip jau buvo minèta, sutikimai yra išreikšti formaliai, t. y. visų lygių visose sporto šakose sportininkas pasirašo sutartis (kontraktus) tarp žaidèjo ir klubo ar organizacijos, kuriems jis priklauso. Šios sutartys yra detalios, jose aptariamos visos galimos sportininko karjeros situacijos, susijusios su sportine veikla klube ar organizacijoje. Todèl sportininko sutikimu laikytina pasirašoma sutartis (kontraktas). 


\subsection{Sutikimo turinys ir apimtis}

Kyla klausimas, kokia išreikšto sutikimo apimtis, t. y. su kokiais varžovo veiksmais ir kilusiais padariniais sportininkas sutinka. Manytina, kad galima pritarti Naujosios Zelandijos teismo pasiūlytiems objektyviems universaliems kriterijams, leidžiantiems identifikuoti sutikimo ribas ir šių ribų apimtis ${ }^{33}$ :

a) žaidimo prigimtis - žaidimo taisyklès (rašytinès, nerašytinès) tradicijos ir žaidime keliami uždaviniai;

b) veiksmo pobüdis - panaudoto veiksmo reikalingumas (atsižvelgiant ị konkrečią situaciją), pavojingumas, rizikingumas, veiksmo atlikimo technika, veiksmo keliamos grèsmès tikimybé;

c) panaudotos jégos laipsnis - adekvati, intensyvi, šiurkšti, grubiai taisykles pažeidžianti jega;

d) sužalojimo pavojingumo laipsnis - sveikatos sutrikdymo mastas (nežymus, nesunkus, sunkus sveikatos sutrikdymas, gyvybès atemimas);

e) sportininko büsena veiksmo metu - kaltès forma (tyčia ar neatsargumas), veikimo tikslai ir motyvai.

Manytina, kad vadovaujantis šiais universaliais kriterijais galima ịvertinti visose sporto šakose duodamo sutikimo apimtị. Sutikimo būti sužeistam apimtis bus proporcingai nedidelẻ badmintono varžybose ir proporcingai didele bokso varžybose. Todèl ịvertinus konkrečios sporto šakos prigimtị (taisykles, tradicijas), sportininko atlikto veiksmo pobūdị, panaudotos jègos laipsnị, padaryto sveikatos sutrikdymo mastą bei sportininko būseną konkrečioje žaidimo situacijoje - galima nuspręsti, ar kilusi žala sveikatai patenka ị sutikimo apimtị, ar ne.

Paminètinas atvejis, kai ledo ritulio žaidèjas smogè kitam žaidejui lazda ị kaklo sritį, taip sukeldamas sveikatos sužalojimą burnos ir veido srityje, taip pat laikiną paralyžių nugaros srityje. Nukentejusysis sutiko su galima sužeidimų rizika, tačiau teismas pasisakè, kad: „Yra natūralu, jog žaidèjai, žaidžiantys ledo rituli, sutinka su tam tikra tiesioginio kontakto rizika, tačiau šiu susidūrimu forma yra apibrėžta žaidimo taisyklesse. Kita vertus, ir taisykliu pažeidimas, kuris yra nerašyta žaidimo dalis, taip pat gali patekti $i$ žaidèjo duoto sutikimo apimtį. Tačiau žaidèju duoti sutikimai dèl fiziniu susidūrimu neapima visu galimu susidūrimų. "Pasak teismo, ì sutikimo apimtị nepatenka brutalios ir žiaurios atakos prieš žaidèjus.

Todèl kalbant apie sutikimo apimtị, būtina kalbèti apie padarinių mastą. Svarbu aptarti, kokius padarinius gali apimti žaidèjo sutikimas - nežymų, nesunkų, sunkų sveikatos sutrikdymą ar net gyvybės atėmimą? Atsakymas glūdi prieš tai pateiktų kriterijų turinyje. Tai reiškia, kad atsižvelgiant ị sporto šakos žaidimo prigimtį, atlikto veiksmo pobūdị, panaudotos jègos laipsnị, padaryto sveikatos sutrikdymo mastą bei sportininko būseną konkrečioje situacijoje, galima spręsti, koks sveikatos sutrikdy- 
mas yra pateisinamas sportininko sutikimu. Todèl net ir nežymus sveikatos sutrikdymas gali išeiti už sportininko sutikimo ribų, tuo tarpu sunkus sveikatos sutrikdymas gali patekti ị sportininko duoto sutikimo apimti.

Todèl teismas spręsdamas bylą turètų vertinti konkrečią situaciją vadovaudamasis pateiktais kriterijais ir nuspręsti, ar padaryti sveikatos sutrikdymai turi būti ịvertinti baudžiamuoju isstatymu, ar vis dèlto tai patenka i sportininko duoto sutikimo ribas.

\subsection{Ar tiesioginè tyčia sutrikdyti sveikatą sportininko duotą sutikimą daro niekinị?}

Pažymėtina, kad i sportininko sutikimo apimti gali patekti ir neatsargus, ir tyčinis taisyklių pažeidimas, tačiau kilusių padarinių atžvilgiu galima tik neatsargi kaltès forma. Derètų sutikti su A. N. Krasikovu, teigiančiu, kad asmuo neturètų būti traukiamas baudžiamojon atsakomybėn, kai neatsargiai pažeisdamas žaidimo taisykles sukelia sveikatos sutrikdymus, kadangi neatsargus taisyklių pažeidimas neteisètų veiksmų atveju nepasiekia pakankamo pavojingumo laipsnio, už kurị derètų traukti asmenị baudžiamojon atsakomybèn (pvz., futbolininkas spiria ị kamuolị, tačiau dèl pasikeitusios varžovo kūno padèties pataiko pastarajam ị koją, dẻl ko šiam sutrikdo sveikatą).

Kita vertus, A. A. Skvorcovas teigia, kad sportininko, pažeidusio žaidimo taisykles dèl neatsargumo, tačiau sukèlusio sunkius padarinius - sunkų sveikatos sutrikdymą ar net gyvybės atėmimą, veiksmai turi užtraukti baudžiamąją atsakomybę, kadangi gyvybė yra svarbiausia baudžiamojo įstatymo saugoma vertybè, todèl, jo manymu, nepateisinamos aplinkybės, kai vienas asmuo atima gyvybę kitam asmeniui. Vis dèlto manytina, kad neatsargus taisyklių pažeidimas, net ir sukèlęs sunkius padarinius, patenka ị sportininko sutikimo apimtị. I sportininko sutikimo apimtị patenka ir atvejai, kai sportininkas tyčia pažeidžia taisykles, tačiau padarinių atžvilgiu veikia neatsargiai.

Rusų autoriai teigia, kad jei sportininkas pažeidžia žaidimo taisykles dẻl neatsargumo, tai jam gali būti pritaikytos tik tos sankcijos, kurios numatytos žaidimo taisyklèse. Tačiau jeigu pažeidimai yra sukeliami ne žaidimo metu, bet, pavyzdžiui, muštynių aikštelèje metu, tokias situacijas derètų vertinti kaip tyčinị kūno sužalojimą baudžiamosios teisès prasme ${ }^{34}$.

Pateikiant tyčinị sveikatos sutrikdymo pavyzdị, derètų paminèti 2009 metais vykusias Olandijos lygos futbolo varžybas tarp Zinkwegse Boys ir Bolnes komandų, kai vienos komandos žaidejjas už agresyvų žaidimą gavo raudoną kortelę ir buvo išvarytas iš aikštės. Beeidamas iš aikštès žaidèjas pribėgo prie gulinčio varžovo, prieš kurị prasižengè, ir stipriu kojos smūgių spyrè jam ị galvos sritị. Smūgị matę žaidèjai teigè,

34 Bezručko, E. V. Ugolovnaja otvetstvenost za prichenenie vreda zdorovju cheloveka. [Criminal liability for making damage health of person]. Rostov, 2001, p. 153. 
kad smūgio stiprumas buvo toks, lyg šis spirtų baudos smūgị i kamuolį. Nukentėjusiajam buvo suskaldyta kaukolè, o kaltininkas buvo nuteistas trejiems metams laisvès atėmimo ${ }^{35}$. Todèl tyčinis taisyklių pažeidimas ir padarinių siekimas vienareikšmiškai išeina už sportininko duoto sutikimo ribų.

Kanadoje laikomasi pozicijos, kad kaltinamasis negali gintis nukentejusiojo sutikimu, jei sveikatos sutrikdymas buvo padarytas turint tyčią sutrikdyti sveikatą nukentejjusiajam $^{36}$. Trumpai tariant, tiesioginè tyčia sutrikdyti sveikatą sportininko sutikimą daro niekinị. Didžiosios Britanijos teismai mano, kad sveikatos sutrikdymai, padaryti tyčia, neturi jokio gynybinio imuniteto teismo procese. Bastin J stated in Agar v Canning byloje teismas konstatavo, kad: „Situacijose, kai iš aplinkybiu galima spręsti, kad sveikatos sutrikdymai, padaryti tyčia siekiant sukelti sunkius sužalojimus, net ir tais atvejais, kai kaltininkas buvo provokuojamas ar tai buvo padaryta žaidimo ikarštyje, neturètu büti vertinama atsižvelgiant ị sportininko sutikima ir turètų užtraukti baudžiamaja atsakomybę. ${ }^{\text {"37 }}$

Kalbant apie Lietuvos teisę, taikant BK 38 straipsnị, derètų sutikti, kad tyčia sutrikdyti sveikatą sporto varžybų metu turi būti vertinama kaip šiurkštus varžybų taisyklių pažeidimas, dèlt ko neturètų būti taikoma norma, atleidžianti nuo baudžiamosios atsakomybès.

Todèl darytina išvada, kad tiesioginè tyčia sužaloti varžovą varžybų metu sportininko sutikimą daro niekinị ir išeina už jo ribų.

\section{Procesinès baudžiamosios atsakomybès prielaidos}

\subsection{Viešasis interesas kaip prielaida pradèti baudžiamąji procesą}

Viešasis interesas - tai visuomenei svarbi vertybė, gèris, kurio užtikrinimu turi rūpintis valdžios ịstaigos (taip pat ir viešojo administravimo subjektai) ir ị kurị neatsižvelgus būtų pažeistos ne vieno, o daugelio žmonių teisès ir teisèti interesai ${ }^{38}$.

35 Kerr, J. H. Analysis of recent incidents of on-field violence in sport: legal decisions and additional considerations from psychology. Aggressive Behavior. 2009 [interaktyvus]. Vol. 35, Issue 1: 41 [žiūrèta 2014-07-11]. <http://web.b.ebscohost.com/ehost/viewarticle?data=dGJyMPPp44rp2 \%2fdV0\%2bnjisfk5Ie45PFJt6uxSbSk63nn5Kx95uXxjL6orUm1pbBIr6qeS7ipt1Kxq55Zy5zyit \%2fk8Xnh6ueH7N\%2fiVaunr0mzp7VQtKm3PurX7H\%2b72\%2bw\%2b4ti7ebfepIzf3btZzJzfh rups0\%2bvrK9Qt5zkh\%2fDj34y75uJ\%2bxOvqhNLb9owA\&hid=119>.

$36 R$ v. Jobidon [1991] 2 SCR 714 [interaktyvus]. [žiūrèta 2014-07-11]. <http://scc-csc.lexum.com/ $\mathrm{scc}-\mathrm{csc} / \mathrm{scc}-\mathrm{csc} / \mathrm{en} / \mathrm{item} / 784 /$ index.do>.

37 Johnson v. Webb [2001] MBQB 290 [interaktyvus]. [žiūrèta 2014-07-11]. <http://caselaw. canada.globe24h.com/0/0/manitoba/court-of-queen-s-bench-of-manitoba/2002/02/01/ johnson-v-webb-2001-mbqb-290.shtml >.

38 Viešasis interesas ir jo gynimas. [interaktyvus]. [žiūrèta 2014-07-12]. <http://www3.lrs.lt/ docs2/UIITBLSY.PDF>. 
Viešajj interesą ir jo buvimą galima pagrịsti tuo, kad sportas yra visuomenèje itin svarbi sritis, kurią stebi didžioji dalis visuomenès. Stebint profesionalias sporto varžybas visuomenė tikisi gražaus reginio, kuris vyktų pagal žaidimo taisykles, palaiko mègstamus sportininkus, laukia jų tobulejimo. Todẻl šiurkštūs žaidimo taisyklių pažeidimai, sukèlę sveikatos sutrikdymus sportininkams, kelia visuomenès nepasitenkinimą ir pasipiktinimą bei pažeidžia teisètus interesus. Lygiai tokius pačius išgyvenimus jaučia ir sportininkai, kurie varžosi ar stebi kitų žaidejjų varžybas. Kita vertus, yra autorių, teigiančių, jog sportininkai žino, kad jeigu bus panaudota agresija arba pažeistos taisyklès, treneriai, o ypač komandų savininkai (taip pat ir žiūrovai) jų nepasmerks, kadangi visiems svarbiausia yra ne tai, kaip žaidèjas žaidžia, bet ar jis arba komanda laimi ${ }^{39}$.

Todèl neabejotina, kad agresyvūs ir šiurkštūs taisyklių pažeidimai, sukeliantys sveikatos sutrikdymus ir nepatenkantys ị žaidejo sutikimo apimtị - prieštarauja viešajam interesui.

Pažymėtina, kad smurtas sporto aikštėse gali išprovokuoti ir žiūrovų smurtą ir tapti elgesio pavyzdžiu jauniesiems sportininkams ${ }^{40}$. Mihaela Rocica Marasescu straipsnyje apie sportininkų įtraukimą i agresiją prisidengiant sporto varžybų tikslais, vienareikšmiškai teigia, kad sportininkų pripratinimas prie agresijos sporte neabejotinai sukelia padarinius už sporto aikštelès ribų ${ }^{41}$. Taip pat gali būti pavyzdžiu ir plačiajai visuomenei, ypač jaunimui.

Todèl derètų teigti, kad tyčinis fizinis smurtas sporto varžybų metu pažeidžia viešąji interesą.

\subsection{Ar reikalingas nukentejjusiojo asmens skundas?}

Vienareikšmiškai atsakyti ị ši kausimą nèra paprasta, kadangi yra galimybė, jog nukentèjusysis nesikreips ị teisèsaugos institucijas, tačiau žaidimo taisyklès galèjo būti pažeistos itin agresyviai ir brutaliai, o sportininkui padaryti sunkūs kūno sužalojimai. Todèl kyla klausimas, ar prokuroras, gavęs duomenų apie padarytą nusikalstamą veiką, privalo pradèti ikiteisminị tyrimą?

Manytina, kad kaltininkas, tyčia sutrikdęs sveikatą sportinių varžybų metu, turètų būti traukiamas baudžiamojon atsakomybèn tik esant nukentejjusiojo asmens

39 Skvorcov, A. A., supra note 5, p. 63.

40 Bradley, C Nielson Controlling Sports Violence: Too Late for the Carrots - Bring on the Big Stick. (1989) 74 lowa LR 681 at 687.

41 Marasecu, M. R. Athletes involvement in violance and aggression within the context of sports competition. Contemporary Readings in Law \& Social Justice. 2013, Vol. 5, Issue 2: 187 [interaktyvus]. [žiūretta 2014-07-13]. <http://web.b.ebscohost.com/ehost/viewarticle?data=d GJyMPPp44rp2\%2fdV0\%2bnjisfk5Ie45PFJt6uxSbSk63nn5Kx95uXxjL6orUm1pbBIr6qeS7ipt 1Kxq55Zy5zyit\%2fk8Xnh6ueH7N\%2fiVaunr0mzp7VQtKm3PurX7H\%2b72\%2bw\%2b4ti7ebf epIzf3btZzJzfhruvsUuwrK9Ir5zkh\%2fDj34y75uJ\%2bxOvqhNLb9owA\&hid=119>. 
skundui. Tai pagrịstų faktą, jog kaltininko padaryti veiksmai, sukèlę sveikatos sutrikdymą, neabejotinai viršija sportininko (nukentejjusiojo) sutikimo apimtį. Toks skundas būtų aiški nukentẻjusiojo valios išraiška, kad būtent kaltininko padaryti veiksmai prieštarauja žaidimo taisyklèms ar šiurkščiai jas pažeidžia, ir su tokiu elgesiu sportininkas nesutinka.

Kita vertus, prieš tai aptartas viešojo intereso pažeidimas gali pastūmėti vadą pradèti ikiteisminį tyrimą, kadangi neteisèti sportininko veiksmai kelia plataus masto nepasitenkinimą visuomeneje. Atkreiptinas dèmesys, kad prokuroras gindamas viešąji interesą gali inicijuoti ikiteisminị tyrimą už BK XVII bei XVIII skyriuje numatytas veikas, nukreiptas prieš žmogaus sveikatą bei gyvybę.

Atkreiptinas dẻmesys, jog pateikti pareiškimą ar skundą dẻl galimos nusikalstamos veikos padarymo turi turèti teisę ir juridinis asmuo - sporto organizacija, federacija, sporto klubas. Atsižvelgiant ị BK 20 straipsnio 1 dalies turini - juridinis asmuo atsako tik už nusikalstamas veikas, už kurių padarymą Baudžiamojo kodekso specialiojoje dalyje numatyta juridinio asmens atsakomybe. Tuo tarpu BK XVII ir XVIII skyriuose tokia galimybė numatyta tik neatsargaus gyvybės atėmimo ir neatsargaus sunkaus sveikatos sutrikdymo atvejais, kai tai padaryta pažeidžiant teisés aktų nustatytas specialias elgesio saugumo taisykles. Todèl praktikoje gali kilti sunkumų siekiant patraukti sporto klubą, organizaciją ar federaciją už tyčinius nesunkius ar sunkius sveikatos sutrikdymus.

\section{Ultima ratio principo igyvendinimas, taikant baudžiamąją atsakomybę už fizinio smurto naudojimą sporte}

\subsection{Teisminio ir neteisminio ginčų nagrinejjimo institucijos}

Galima skirti du galimus nusikalstamos veikos nagrinèjimo būdus - teisminị ir neteismini. Pirmasis, teisminis, tai jau aptartas - ikiteisminio tyrimo inicijavimas esant nusikalstamos veikos sudéčiai. Antrasis - sporto federacijos priimami sprendimai ir taikomos sankcijos šiurkščiai taisykles pažeidusiems sportininkams.

Anglijos apeliacinis teismas konstatavo, kad: „Daugelis sporto organizaciju turi savo prievartos priemoniu ir bausmiu taikymo procedüras federacijos viduje, todèl nèra bütinybès taikyti baudžiamosios teisès nuostatų. Sportininkai, patyrę sveikatos sutrikdymus, taip pat gali kreiptis ị teisma su ieškiniu dèl žalos atlyginimo. Nors tam tikrais atvejais pagrindas kreiptis civiline ir baudžiamaja tvarka gali sutapti, vis dellto baudžiamaja teisę derètu taikyti tik tada, kai nusikaltimo laipsnis pakankamai aukštas, o nusikaltimas pakankamai sunkus ir nemažareikšmis. ${ }^{" 42}$ 
Analizuojant federacijų taikomas prievartos priemones sportininkams, manytina, kad tai pakankamai efektyvios priemonès, ypač turint omenyje profesionalų sportą. Federacijos taiko sankcijas sportininkus diskvalifikuodamos iš varžybų, taip pat drausdamos žaisti tam tikrą skaičių ateities varžybų. Negana to, yra taikomos piniginès baudos, kurias, šiurkščiai taisykles pažeidę sportininkai, privalo sumokèti federacijai. Todèl manytina, kad tokios prievartos priemonès sportininkams yra pakankamai efektyvios, kadangi profesionaliems sportininkams nèra naudinga praleisti varžybas bei mokèti baudas. Manytina, kad plačiąja prasme šiomis priemonèmis pasiekiami atpildo tikslai.

Tačiau yra mokslininkų, manančių, kad neteisminiai ginčų sprendimo būdai yra žalingi, kadangi neretais atvejais sportininkų, šiurkščiai pažeidusių ịstatymų saugomas vertybes, elgesys lieka neịvertintas, kadangi klubo, lygos ar federacijos skiriamos bausmès ir nuobaudos dažnai yra per lengvos. Taip yra todèl, kad skiriant nuobaudas sportininkams ì pirmą vietą keliami sporto federacijos interesai, dèl ko sportininkai dažnai lieka adekvačiai nenubausti ${ }^{43}$.

Vis dèlto manytina, kad už tikslingus ir tyčinius sveikatos sutrikdymus, šiurkščiai pažeidžiančius sportinius tikslus bei išeinančius už sportininko sutikimo ribų baudžiamosios atsakomybès taikymas yra adekvati atsakomybès forma ir toks teisinis ivvertinimas nepažeidžia ultima ratio principo, kadangi tokie veiksmai akivaizdžiai prieštarauja viešajam interesui bei agresyviai kèsinasi ị vienas svarbiausių baudžiamojo ịstatymo saugomų vertybių - sveikatą ir gyvybę.

\section{Išvados}

1. Fizinis smurtas sporto varžybų metu gali reikštis tiek teisètais, tiek neteisètais veiksmais. Skiriamos šios fizinio smurto, naudojamo varžybų metu, rūšys: a) stiprus fizinis kontaktas, b) ribinis smurtas, c) kvazikriminalinis smurtas, d) kriminalinis smurtas. Baudžiamajai atsakomybei svarbus tik kriminalinis smurtas.

2. Daugelio užsienio valstybių baudžiamieji ịstatymai numato baudžiamąją atsakomybę šalinančią aplinkybę už sveikatos sutrikdymus, padarytus sporto varžybų metu, kai tai buvo padaryta nepažeidžiant žaidimo taisyklių ir veikiant neatsargia kaltès forma padarinių atžvilgiu. Lietuvoje baudžiamąją atsakomybę šalinanti aplinkybè, numatyta LR BK 34 straipsnyje (Pateisinama profesine ar ükinè rizika), galètú būti taikoma asmenims, sporto varžybų metu atlikusiems teisėtus veiksmus, kuriais buvo sukelta žala sveikatai.

43 Young, K. J.; Parlow, M. J. Off-court misbehavior: sports leagues and private punishment. Journal of Criminal Law \& Criminology. 2009, Vol. 99, Issue 3: 573 [interaktyvus]. [žiūrèta 2014-07-13]. <http://web.b.ebscohost.com/ehost/viewarticle?data=dGJyMPPp44rp2\%2fdV0 \%2bnjisfk5Ie45PFJt6uxSbSk63nn5Kx95uXxjL6orUm1pbBIr6qeS7ipt1Kxq55Zy5zyit\%2fk8Xn h6ueH7N\%2fiVaunr0mzp7VQtKm3PurX7H\%2b72\%2bw\%2b4ti7i\%2bfepIzf3btZzJzfhruqsk \%2buqbNQt5zkh\%2fDj34y75uJ\%2bxOvqhNLb9owA\&hid=119>. 
3. Sportininkai dalyvaudami varžybose sutinka (numato, kaip realiai tikètinus) su galimais susidūrimais ir sveikatos sutrikdymais varžybų metu (dalis atsakomybès perkeliama jiems patiems). Toks sutikimas patenka ị pateisinamos profesinès rizikos apimtị. Teismui sprendžiant dèl jų sutikimo turinio ir apimties derètų atsižvelgti ị: a) žaidimo prigimtį, b) veiksmo pobūdį, c) panaudotos jégos laipsnį, d) sužalojimo pavojingumo laipsnį, e) sportininko büsena veiksmo atlikimo metu.

4. Būtinos baudžiamosios atsakomybès už fizinio smurto varžybų metu naudojimą sąlygos yra tiesioginè tyčia pažeisti žaidimo taisykles ir sutrikdyti varžovo sveikatą ar atimti gyvybę. Tiesioginè tyčia sutrikdyti sveikatą ar atimti gyvybę išeina už sportininko sutikimo apimties ribų, dèl ko profesinè rizika nèra pateisinama ir turi būti ivvertinta baudžiamosios teisès priemonemis.

5. Smurtas sporto aikštėse gali išprovokuoti ir žiūrovų smurtą bei tapti elgesio pavyzdžiu jauniesiems sportininkams. Agresyvus sportininkų elgesys varžybų metu sukelia padarinius už sporto aikštelès ribų bei tampa pavyzdžiu ir plačiajai visuomenei, todèl taip veikiant yra pažeidžiamas viešasis interesas.

6. Baudžiamosios atsakomybès taikymas už tyčinius sveikatos sutrikdymus sporto varžybų metu neprieštarauja ultima ratio principui.

\section{Literatūra}

Baranskaite, A. Lietuvos Respublikos baudžiamojo kodekso komentaras. Bendroji dalis [interaktyvus]. [žiürèta 2014-07-13]. <http://web.b.ebscohost. com/ehost/viewarticle?data $=\mathrm{dGJyMP}$ Pp44rp2\%2fdV0\%2bnjisfk5Ie45PFJt6 uxSbSk63nn5Kx95uXxjL6orUm1pbB Ir6qeS7ipt1Kxq55Zy5zyit\%2fk8Xnh6 ueH7N\%2fiVaunr0mzp7VQtKm3Pu rX7H\%2b72\%2bw\%2b4ti7ebfepIzf3bt ZzJzfhruosUqyqrdQr5zkh\%2fDj34y7 5uJ\%2bxOvqhNLb9owA\&hid=119>.

Barnes, R. v [2004] EWCA Crim 3246 (21 December 2004). [interaktyvus]. [žiürèta 2014-07-13]. <http:// www.bailii.org/ew/cases/EWCA/ Crim/2004/3246.html>.

Bezručko, E. V. Ugolovnaja otvetstvenost za prichenenie vreda zdorovju chelove- $k a$. [Criminal liability for making damage health of person]. Rostov, 2001.

Bradley C Nielson „Controlling Sports Violence: Too Late for the Carrots Bring on the Big Stick"(1989) 74 lowa LR 681 at 687.

Criminal Code of USA (English and French) [interaktyvus]. [žiūrèta 201407-06]. <http://www.law.cornell.edu/ uscode/text/18/part-I>.

Criminal code of the Federal Republic of Germany (English and French) [interaktyvus]. [žiūrèta 2014-07-06]. $<$ http://www.legislationline.org/documents/section/criminal-codes $>$.

Criminal Code of Spain (English and French) [interaktyvus]. [žiürèta 2014-0706]. <http://www.legislationline.org/ documents/section/criminal-codes $>$.

Criminal Code of Georgia (English and French) [interaktyvus]. [žiūrèta 2014- 
07-06]. <http://www.legislationline.org/ documents/section/criminal-codes $>$.

Criminal Code of Canada (English and French) [interaktyvus]. [žiūrèta 201407-06]. <http://www.legislationline.org/ documents/section/criminal-codes $>$.

Criminal Code of Afganistan [interaktyvus]. [žiūrèta 2014-07-06].

Gardiner „Should more matches end in court?" BKL. Sports law / Simon Gardiner ... [et al.]. 3rd ed. Abingdon : Cavendish Publishing, 2006. lxii,. : lent., iliustr.

Grinevičiūtè, K. Žiauraus elgesio su vaiku samprata baudžiamojoje teisèje. Jurisprudencija. 2008, 11(113).

Guilbert, Sébastien. Violence in sports and among sportsmen: a single or two-track, Issue? Aggressive Behavior. 2006, Vol. 32, Issue 3 [interaktyvus]. [žiūrèta 2014-07-07]. <http:// web.b.ebscohost.com/ehost/viewarticl e?data $=$ dGJyMPPp44rp2\%2fdV0\%2b njisfk5Ie45PFJt6uxSbSk63nn5Kx95u XxjL6orUm1pbBIr6qeS7ipt1Kxq55Zy 5zyit\%2fk8Xnh6ueH7N\%2fiVaunr0m zp7VQtKm3PurX7H\%2b72\%2bw\%2 b4ti7ebfepIzf3btZzJzfhruotkyzrLdKtp zkh\%2fDj34y75uJ\%2bxOvqhNLb9ow A\&hid $=119>$.

Europos Konvencija dèl brutalaus žiūrovų elgesio per sporto varžybas ir ypač per futbolo rungtynes [interaktyvus]. [žiūrèta 2014-07-06]. <http:// www3.lrs.lt/pls/inter3/dokpaieska. showdoc_l?p_id=104182\&p_tr2=2>.

Futbolo košmarai: Luisas Suarezas vèl kandžiojasi? [interaktyvus]. [žiūrèta 2014-07-05]. <http://www.zinios.lt/ sportas/zinia/2014/06/24/futbolokosmarai-liusas-suarezas-vel-kandziojasi/>.
Hockey Lietuva-Serbija mustynes/ Fighting in ice hockey. interaktyvus]. [žiūrèta 2014-07-05]. <http://www.youtube.com/watch?v=lL_MLSTrfhg $>$.

Mike Tyson vs Evander Holyfield II. [interaktyvus]. [žiūrèta 2014-07-05]. <http://www.youtube.com/watch?v= fcXYEIhy-rc $>$.

Johnson v. Webb [2001] MBQB 290. [interaktyvus]. [žiūrèta 2014-07-11]. <http://caselaw.canada.globe 24 h. com/0/0/manitoba/court-of-queensbench-of-manitoba/2002/02/01/ johnson-v-webb-2001-mbqb-290. shtml>.

Viešasis interesas ir jo gynimas [interaktyvus]. [žiūrèta 2014-07-12]. <http:// www3.lrs.lt/docs2/UIITBLSY.PDF>.

Young, K. J.; Parlow, M. J. Off-court misbehavior: sports leagues and private punishment. Journal of Criminal Law \& Criminology. 2009, Vol. 99, Issue 3 [interaktyvus]. [žiūrèta 201407-13]. <http://web.b.ebscohost.com/ ehost/viewarticle?data=dGJyMPPp4 4rp2\%2fdV0\%2bnjisfk5Ie45PFJt6ux SbSk63nn5Kx95uXxjL6orUm1pbBI r6qeS7ipt1Kxq55Zy5zyit\%2fk8Xnh6 ueH7N\%2fiVaunr0mzp7VQtKm3Pu rX7H\%2b72\%2bw\%2b4ti7i\%2bfepIz f3btZzJzfhruqsk\%2buqbNQt5zkh\%2 fDj34y75uJ\%2bxOvqhNLb9owA\&h $\mathrm{id}=11>$.

Kerr, J. H. Analysis of recent incidents of on-field violence in sport: legal decisions and additional considerations from psychology. Aggressive Behavior. 2009, Vol. 35, Issue 1 [interaktyvus]. [žiūrèta 2014-07-11]. <http:// web.b.ebscohost.com/ehost/viewarticl $\mathrm{e}$ ?data $=\mathrm{dGJyMPPp} 44 \mathrm{rp} 2 \% 2 \mathrm{fdV} 0 \% 2 \mathrm{~b}$ njisfk5Ie45PFJt6uxSbSk63nn5Kx95u 
XxjL6orUm1pbBIr6qeS7ipt1Kxq55Zy

5zyit\%2fk8Xnh6ueH7N\%2fiVaunr0m zp7VQtKm3PurX7H\%2b72\%2bw\%2 b4ti7ebfepIzf3btZzJzfhrups0\%2bvrK9 Qt5zkh\%2fDj34y75uJ\%2bxOvqhNLb 9owA\&hid=119.

Lietuvos Respublikos baudžiamasis kodeksas. Valstybès žinios. 2000, Nr. 1968. 34 str.

Livings, B. 'Legitimate Sport' or Criminal Assault? What Are the Roles of the Rules and the Rulemakers in Determining Criminal Liability for Violence on the Sports Field? Journal of Criminal Law. 2006, Vol. 70, Issue 6 [interaktyvus]. [žiūrèta 2014-07-05].

Marasecu, M. R. Athletes involvement in violance and aggression within the context of sports competition. Contemporary Readings in Law \& Social Justice. 2013, Vol. 5, Issue 2 [interaktyvus]. [žiūrèta 2014-07-13]. <http://web.b.ebscohost.com/ehost/vi ewarticle?data=dGJyMPPp44rp2\%2fd V0\%2bnjisfk5Ie45PFJt6uxSbSk63nn5 Kx95uXxjL6orUm1pbBIr6qeS7ipt1K xq55Zy5zyit\%2fk8Xnh6ueH7N\%2fiV aunr0mzp7VQtKm3PurX7H\%2b72\% 2bw\%2b4ti7ebfepIzf3btZzJzfhruvsUu wrK9Ir5zkh\%2fDj34y75uJ\%2bxOvqh NLb9owA\&hid=119>.
Piesliakas, V. Lietuvos baudžiamoji teisè. Pirmoji knyga. Vilnius: Justitia, 2009. $R$ v. Cey (1989), 48 CCC (3d) 480 (Sask CA) [interaktyvus]. [žiūrèta 2014-0705].<http://casebrief.me/casebriefs/ r-v-cey/>.

Simon Gardiner ... [et al.]. 3rd ed. Abingdon: Cavendish Publishing, 2006. Simon Gardiner and others Sports Law (3rd ed, Routledge-Cavendish, Oxon, 2006).

Skvorcov, A. A. Prichinenija vreda zhizni $i$ zdorovju pri zaniatijam sportom. Problemy ugolovnoj-pravovoj kvalifikacii. [Damage for the health and life at doing sports. Problems of the criminal law qualification]. Moskva, 2006.

Sporto terminu žodynas. Sudarytojas S. Stonkus. Kaunas: Kauno kūno kultūros akademija, 2002.

Standen, J. The manly sports: the problematic use of criminal law to regulate sports violance. Journal of Criminal Law \& Criminology. 2009, Vol. 99, Issue 3 [interaktyvus]. [žiūrèta 2014-07-07].

Zakonodatelstvo Zarubežnych stran. Ugolovnyj kodeks resubliki San-Marino. [Foreign legislation. The criminal code of the republic of San Marino]. Sankt-Peterburg, 2002.

Anotacija. Nagrinejjama Lietuvoje nauja ir moksliškai dar neanalizuota tema fizinio smurto naudojimas sporte ir baudžiamoji atsakomybe už ji. Atsižvelgiant i tai, kad mokslinių straipsnių šia tema bei tokio pobūdžio bylų Lietuvoje dar nèra, straipsnyje analizuojama užsienio šaliu doktrina ir praktika. Pateikiamas teisinis sporto, kaip fizinès veiklos, reglamentavimas. Analizuojami fizinès prievartos atvejai (susidūrimai), šiurkščiai pažeidžiantys sporto taisykles ir galintys užtraukti baudžiamaja atsakomybę. Diskutuojama apie sportininko sutikimo, apimančio galimybę būti sužalotam, turinį ir apimtį. Straipsnyje siekiama pateikti objektyvius kriterijus, leidžiančius 
identifikuoti nusikalstamos veikos padarymo fakta sporto metu. Galiausiai diskutuojama, ar baudžiamosios atsakomybès taikymas už šiurkščius, sportiniams principams bei taisyklèms prieštaraujančius nusižengimus, sukèlusius sveikatos sutrikdyma ar gyvybès atèmimą, nepažeidžia ultima ratio principo.

Reikšminiai žodžiai: baudžiamoji teisé, fizinis smurtas sporte, sveikatos sutrikdymas sporte, sportininko sutikimas.

\title{
CRIMINAL LIABILITY FOR VIOLENCE IN SPORTS
}

\author{
Linas Žalnieriūnas, Aurelijus Gutauskas
}

Mykolas Romeris University, Lithuania

Summary. This article analyzes new and scientifically unanalyzed subject in Lithuania - the use of physical violence in sports and criminal liability for it. The aim of this article is to identify how cruel emotions can influence the use of physical strength and injuries against opponent in sports. The subject of this article is not very popular, nor there are a lot of scientists interested in it in Lithuania, so this article pays a lot of attention of foreign countries doctrine and practice. This is one of the reasons why this subject is so important and significant in academic level. The author of the article tries to explore if intentional physical violence during sport events may result in a criminal liability for assaults.

On the other hand, there are many cases when sport event contestants have a possibility to legally use violence and not even for winning aims. This article intends to provide objective criteria, which would help to identify the fact of criminal offence during sports. Since there are not many scientific researches and Lithuania courts judicial practice on this kind of subject, the author explores foreign countries doctrine and practice for finding the objective criteria as well. This article presents legal regulation of sport, as a physical activity. Moreover, it discusses whether criminal liability for serious, contrary to sports principles misconducts, which lead to body injury or homicide, does not violate the principle of ultima ratio, also analyses physical abuse cases (collisions), gross violations of the rules of sports. Discussing the athletes consent, which includes the possibility of being injured, it's content and scope. It discusses criminal procedure, Issues - the defense of public interest and etc. The main object of this study is to provide potential objective criteria, which will enable the identification of the facts of the offense of physical violence in sports.

Keywords: criminal law, assaults, physical violence in sport, intentional injury in sport. 
Linas Žalnieriūnas, Mykolo Romerio universiteto Teisès fakulteto Baudžiamosios teisès ir proceso instituto lektorius. Mokslinių tyrimų kryptys: baudžiamoji teisé, nuskalstamos veikos vaikui ir šeimai, priežastinis ryšys baudžiamojoje teisèje, smurtas sporte.

Aurelijus Gutauskas, Mykolo Romerio universiteto Teisès fakulteto Baudžiamosios teisès ir proceso instituto profesorius. Mokslinių tyrimų kryptys: baudžiamosios teisès normų aiškinimo, taikymo bei tobulinimo problemos.

Linas Žalnieriūnas, Mykolas Romeris University, Faculty of Law, Institute of Criminal Law and Criminal Procedure, lecturer. Research interests: criminal law, crimes and misdemeanors against child and family, causation in criminal law, violance in sports.

Aurelijus Gutauskas, Mykolas Romeris University, Faculty of Law, Institute of Criminal Law and Criminal Procedure, Professor. Research interests:, Issues of interpretation, aplication and development of criminal law. 